\title{
Fronteiras sexuais no espaço urbano
}

\author{
Jainara Gomes de Oliveira \\ Doutoranda em Antropologia Social do PPGAS/UFSC ${ }^{1}$
}

SABSAY, Leticia. Fronteiras sexuales. Espacio urbano, cuerpos y ciudadanía. Buenos Aires, Paidós, 2011, 172 p.

Este livro de Leticia Sabsay, uma renomada socióloga argentina e especialista em estudos de gênero, foi publicado pela editora Paidós, com prólogo de Judith Butler e está organizado em cinco capítulos, além de uma introdução. No presente livro, Sabsay apresenta uma crítica aos limites de uma democracia da sexualidade, assim como aos marcos normativos e políticos da identidade. Nesse sentido, a análise apresentada aponta para as possibilidades de uma política mais radical das fronteiras sexuais. Trata-se assim de um sistemático trabalho de investigação acerca das políticas sexuais, estas, por sua vez, são analisadas a partir da construção da noção de cidadania e do contexto de democracia. Deste modo, na análise de Judith Butler (2011: 11),

Fronteiras sexuais se pregunta sobre las políticas sexuales en el contexto de la democracia y en este marco se plantea cómo pensar la política espacial mediante la que se constuyen nociones de género y ciudadanía. Desde el punto de vista teórico, Leticia Sabsay reúne un conjunto de perspectivas teóricas y disciplinarias tomando aspectos del postestructaralismo, el materialismo, la teoria de la narrativa y el estudio crítico de ley para interrogar cómo las luchas acerca de quién pude aparecer en el espacio

${ }^{1}$ Pesquisadora do Núcleo de Identidades de Gênero e Subjetividades da UFSC. Bolsista de doutorado do CNPq. 
urbano de Buenos de Aires en los años que siguieron a la caída de la dictadura se convirtieron en una manera de construir la ciudadania en sí mesma (grifos da autora).

O livro de Sabsay, nesse sentido, analisa ainda as regulações do espaço urbano portenho, que emergiram a partir da criação do Código de Convivência Urbana, código este sancionado como resultado das reformas legais que foram realizadas no final dos anos 1990, na Cidade Autónoma de Buenos Aires.

O primeiro capítulo, El sujeto político de la diversidad, interpela o processo de constituição de sujeitos políticos em contextos democráticos. Nesse sentido, o capítulo dedica uma particular atenção ao discurso liberal, que segundo a autora é "pretensamente inclusivo". Este discurso liberal, por sua vez, tem por finalidade a promoção da tolerância e considera a diversidade como uma possibilidade de integração social. No entanto, como apontado pela autora, tal discurso continua a privilegiar a heterossexualidade compulsória como norma e a excluir as sexualidades não normativas de seus marcos legais. Neste sentido, Sabsay discute as tramas do poder que perpassam o processo de constituição de um sujeito político, apontando assim para os limites do paradigma do construtivismo e propondo uma transformação radical do conceito de gênero.

O segundo capítulo, Las zonas rojas de la "democracia sexual", analisa os espaços nos quais o trabalho sexual necessita ser escondido ou limitado, assim como os espaços que são considerados públicos. Deste modo, sua análise evidencia como se materializam a exclusão e a delimitação de fronteiras sexuais de forma normativa. Nesse sentido, este capítulo assinala para o processo no qual formas legítimas de sexualidades são definidas e como a construção de uma hierarquia sexual abre as portas para uma crítica aos limites da democratização da sexualidade.

Em seguida, o terceiro capítulo, El discurso de la ley, problematiza a autoridade da lei, uma vez esta acaba por produzir uma linha divisória entre as sexualidades socialmente legitimadas e as que são consideradas desviantes. Continuando o desenvolvimento deste argumento, a análise apresentada no quarto capítulo, La performatividad del trabajo sexual, problematiza particularmente o artigo do Código de Convivência que se dedica a regular o trabalho sexual e as diversas formas como os sujeitos experimentam os seus desejos, assim o capítulo citado discute a materialidade textual da lei e o debate que a suscitou. Na visão de Sabsay, deste modo, esta lei possibilitou a emergência e a materialização de uma fronteira de exclusão, na qual se instaurou o controle normativo da visibilidade das sexualidades socialmente discriminadas.

No quinto capítulo, El periodismo y la regulación del espacio público, centra sua análise na construção midiática do discurso periodístico. Discurso este que potencializou uma conflituosa produção de fronteiras identitárias no espaço urbano. Como resultado desse conflito entre sociedade e coletivos sexuais segregados, emergiram os sujeitos políticos trans na Argentina. Tal conflito possibilitou também a promoção do debate acerca da inteligibilidade de seus corpos, o que, por sua vez, abriu caminhos para um novo imaginário sociosexual das normas sobre o gênero e a sexualidade.

Fronteiras sexuales, é, portanto, um livro que apresenta uma pertinente análise crítica sobre a categoria gênero com a proposta de construção de uma democracia radical. De tal forma, as análises de Sabsay procuram estabelecer uma leitura crítica das disputas públicas argentinas que tinham por finalidade a 
regulação dos espaços públicos, tendo como foco a presença das profissionais do sexo nestes espaços.

As referidas análises procuravam, do mesmo modo, debater acerca do processo de despenalização do trabalho sexual, assim como sobre a viabilidade de construção de um coletivo de travestis e mulheres transexuais no espaço público. Trata-se assim de um livro que aborda os processos de formações subjetivas, as políticas de identidade, a construção de cidadania e as fronteiras da diversidade sexual e de gênero, categorias estas uteis para uma análise sobre a regulação do espaço público.

A originalidade de seu livro, nesse sentido, se encontra na articulação analítica entre a categoria gênero e sua visibilidade no marco do espaço urbano, esta articulação, por sua vez, se traduz na aplicabilidade de seus conceitos, uma vez que os mesmos permitem uma análise contextual da realidade concentra. Portanto, ao analisar os processos pelos quais subjetividades se expressam em luta política contra a regulação do espaço público, Sabsay abre um horizonte de possibilidades analíticas que podem ser articuladas com os debates sobre os usos, as representações e os pertencimentos daqueles espaços pelos sujeitos políticos. Deste modo, no presente livro, as disputas públicas pelo espaço urbano que foram experienciadas na cidade de Buenos Aires formam uma pertinente chave de leitura para problematizar a incômoda relação entre o Estado e a construção da cidadania. Do mesmo modo, Sabsay aponta para a necessidade de analisar essa relação para além de uma mera luta por concessão de direitos.

O debate sobre as fronteiras da diversidade e o contexto da democracia sexual em Buenos Aires, de um lado, assinala para as implicações que estão presentes na forma como são produzidos os espaços de exclusão, assim como são construídos os ideais de nação e cidadania em articulação com os processos de regulações normativas de identidade de gênero e sexuais. Por outro, Sabsay ressalta a pertinência de se analisar como os sujeitos políticos se relacionam com os seus espaços de participação, a produção de suas identidades política, as possibilidades de aceitação e de respeito do/ao outro, assim como de sua subjetividade e valorização de seus corpos. Corpos estes que desestabilizam os limites da inteligibilidade discursiva e apontam para as novas formas de se construir a cidadania.

Com base no que foi exposto até aqui, pode-se apontar que o livro Fronteiras sexuales de Leticia Sabsay constitui uma pertinente análise sobre os aspectos regulatórios que normatizam a sexualidade e o gênero em contexto de sociedades democráticas e discursivamente inclusivas. Nesse sentido, tomando como estudo de caso a Argentina, o livro lança como proposta uma virada epistemológica em relação a forma como se constitui a luta por reconhecimento pela igualdade de gênero e da diversidade sexual na Argentina, debate que permite impulsionar a sociedade para a reformulação da noção de cidadania vigente, colocando em questionamento os ideais de construção de uma identidade nacional. 